\title{
PENGARUH STRESS KERJA DAN KARAKTERISTIK PERSONAL TERHADAP TURNOVER INTENTION PEGAWAI PADA PERUSAHAAN DI SURALAYA
}

\author{
Try Rahayu ${ }^{1}$, Santi Riana Dewi ${ }^{2}$, Nafiuddin ${ }^{3}$ \\ Fakultas Ekonomi Universitas Serang Raya \\ Email: tryrahayudarso@gmail.com ${ }^{1}$, santirianadewi@yahoo.co.id ${ }^{2}$, \\ nafiuddin08@gmail.com ${ }^{3}$
}

\begin{abstract}
ABSTRAK
Pada saat ini dunia industri sedang mendapat perhatian khusus karena pentingnya peran industri bagi peningkatan kesejahteraan rakyat dan kualitas sumber daya manusia. Selain itu terjadi hal yang bertolak belakang yaitu adanya pemutusan kerja yang disebabkan karena adanya kasus korupsi, kolusi, nepotisme, turnover yang tinggi, menurunnya produktivitas, dan belum optimalnya kinerja pada perusahaan. Oleh karena hal tersebut maka pada penelitian ini sangat menarik untuk mengetahui faktor-faktor dominan yang mempengaruhi turnover intention pegawai. Adapun tujuannya adalah untuk mengetahui besarnya pengaruh stres kerja dan karakteristik personal terhadap turnover intention pegawai pada sebuah perusahaan di Suralaya. Penelitian ini dilakukan dengan menggunakan metode analisis regresi linear berganda. Populasi penelitian berjumlah 110 pegawai, dan diambil sampel sebanyak 84 pegawai divisi operasi unit dengan menggunakan probability sampling. Data primer diperoleh melalui hasil kuesioner dan data sekunder diperoleh dari hasil wawancara dan laporan perusahaan. Berdasarkan hasil penelitian dapat disimpulkan bahwa :1) Terdapat pengaruh negatif yang signifikan antara stres kerja dan turnover intention pegawai tetap divisi operasi unit, 2) Terdapat pengaruh yang signifikan antara karakteristik personal dan turnover intention pegawai tetap divisi operasi unit, 3) Terdapat pengaruh yang signifikan antara stres kerja dan karakteristik personal terhadap turnover intention pegawai tetap divisi operasi unit. Adapun hasil dari penelitian ini, diharapkan akan menjadi bahan pertimbangan dasar pengambilan keputusan manajemen perusahaan untuk menurunkan angka turnover pegawai.
\end{abstract}

Katakunci : karakteristik personal, stres kerja, turnover intention.

\begin{abstract}
ABSTRACK
At present the industrial world is getting special attention because of the importance of the role of industry in improving people's welfare and the quality of human resources. Besides that, the opposite happened, namely the termination of employment caused by cases of corruption, collusion, nepotism, high turnover, decreased productivity, and unoptimal performance in the company. Because of this, this study is very interesting to find out the dominant factors that influence employee turnover intention. The purpose is to determine the magnitude of the influence of work stress and personal characteristics on employee turnover intention at a company in Suralaya. This research was conducted using the method of multiple linear regression analysis. The study population amounted to 110 employees, and a sample of 84 employees in the unit operating division was taken using
\end{abstract}


probability sampling. Primary data obtained through questionnaire results and secondary data obtained from interviews and company reports. Based on the results of the study it can be concluded that: 1) There is a significant negative effect between work stress and permanent employee turnover intention of the operation unit division, 2) There is a significant influence between personal characteristics and turnover intention of permanent employees operation unit division, 3) There is a significant influence between work stress and personal characteristics of the turnover intention of permanent employees in the operation unit division. The results of this study are expected to be a basic consideration of the company's management decision-making to reduce employee turnover rates.

Keyword: personal characteristic, turnover intention, work stress.

\section{Pendahuluan}

Terdapat beberapa faktor yang menyebabkan tingginya intensitas turnover pada perusahaan, antara lain stres kerja dan karakteristik personal. Tingginya turnover akan mempengaruhi kestabilan proses kerja dikarenakan pegawai yang tidak menentu sebagai pelaksana untuk menghasilkan produk barang ataupun jasa yang dihasilkan. Turnover atau pergantian tenaga kerja merupakan wujud nyata dari turnover intention yang dapat menjadi masalah serius bagi perusahaan atau organisasi, khususnya apabila yang keluar adalah tenaga kerja yang mempunyai keahlian, kemampuan, terampil dan berpengalaman atau tenaga kerja yang menduduki posisi vital dalam perusahaan, sehingga dapat menganggu efektivitas jalannya perusahaan.

Tingginya tingkat turnover intention karyawan pada perusahaan menjadi salah satu hal penting yang harus menjadi perhatian perusahaan. Karena, bukan hal yang mudah bagi perusahaan untuk meminimalisir tingkat turnover intention yang terus meningkat dari waktu ke waktu. Keluar masuknya karyawan dari perusahaan adalah suatu fenomena penting dalam kehidupan perusahaan. Pergantian karyawan ada kalanya berdampak positif namun, sebagian besar pergantian karyawan membawa pengaruh negatif terhadap perusahaan, baik dari segi biaya maupun dari segi hilangnya waktu dan kesempatan untuk memanfaatkan peluang.

Berikut ini adalah konsep mengenai turnover intention. Menurtu Harnoto (2002:2 dalam Arin dkk. 2014) menyatakan, turnover intention adalah kadar atau intensitas dari keinginan untuk keluar dari perusahaan, banyak alasan yang menyebabkan timbulnya turnover intention ini dan diantaranya absensi yang meningkat, mulai malas kerja, naiknya untuk melanggar tata tertib kerja, keberanian untuk menentang atau protes kepada atasan maupun keseriusan untuk menyelesaikan semua tanggung jawab pegawai yang sangat 
berbeda dari biasanya. Adapun stres merupakan kondisi ketegangan yang berpengaruh terhadap emosi, jalan pikiran dan kondisi fisik seseorang. Adapun konsep dari stres kerja adalah suatu kondisi yang dinamik di dalam individu untuk menghadapi peluang, kendala, atau tuntutan yang berhubungan dengan hal-hal yang diinginkan dan hasilnya dipersepsikan sesuatu yang tidak pasti tetapi penting. (Robbins, 2003). Artinya stres kerja dapat timbul jika terdapat tugas-tugas atau keinginan untuk mencapai suatu target atau tujuan tertentu yang merupakan kebutuhan atau hal-hal yang dianggap berpengaruh dan penting.

Selanjutnya karakteristik personal menurut Gibson, James L yang dialih bahasakan oleh Nunuk Andriani (dalam Rusli 2016:14) bahwa yang dimaksud dengan karakteristik individu adalah kemampuan dan kecakapan, latar belakang dan demografi. Klasifikasi dan demografi adalah jenis kelamin dan ras, perilaku pekerja yang menentukan hasil mereka dapat menghasilkan prestasi jangka panjang yang positif dan pertumbuhan diri atau sebaliknya, prestasi jangka panjang yang jelek atau kurang berkembang.

Berikut ini adalah beberapa penelitian terdahulu yang berkaitan dengan turnover. Dalam penelitian oleh Gabriela Syahronica, Moehammad Soe'oed Hakam, Ika Ruhana, (2015) dari Universitas Brawijaya Malang, melakukan penelitian dengan judul Pengaruh Stres Kerja dan Kepuasan Kerja Terhadap Turnover Intention Karyawan Departemen Dunia Fantasi. Penelitian ini dilakukan pada karyawan Departemen Dunia Fantasi PT Pembangunan Jaya Ancol, Tbk yang berjumlah 55 orang karyawan dan berlokasi di Jl. Lodan Timur No.7 Jakarta. Teknik Analisis data yang digunakan analisis deskriptif dan analisis regresi linier berganda. Dari hasil penelitian ini diketahui adanya pengaruh signifikan dari kepuasan kerja terhadap turnover intention karyawan Departemen Dunia Fantasi PT Pembangunan Jaya Ancol, Tbk, dengan menggunakan metode analisis linear berganda. disini dapat diketahui bahwa kedua variabel bebas tersebut yang dominan pengaruhnya terhadap Turnover Intention adalah stres kerja karena nilai koefisien beta yang lebih besar. Besarnya pengaruh atau kontribusi variabel bebas terhadap variabel terikat. sebesar 0,522. Artinya bahwa 52,2\% variabel turnover intention akan dipengaruhi oleh variabel bebasnya, yaitu kepuasan kerja dan stres kerja. Penelitian lainnya mengenai pengaruh penggunaan teknologi informasi, disiplin kerja, intensif, dan turnover terhadap kinerja pegawai menunjukan hasil bahwa terdapat pengaruh yang signifikan antara teknologi informasi terhadap kinerja, terdapat pengaruh yang signifikan antara disiplin terhadap kinerja, terdapat pengaruh yang signifikan antara insentif terhadap disiplin, dan 
terdapat pengaruh negatif yang signifikan antara insentif terhadap turnover, dan terdapat pengaruh negatif yang signifikan antara turn over terhadap kinerja. (Putu Pande Y dan Gede Sri D, 2015). Selanjutnya penelitian mengenai pengaruh kepuasan kerja dan ketidaknyamanan kerja dengan intensi pindah kerja, menunjukan hasil bahwa terdapat pengaruh antara kepuasan kerja terhadap intensi pindah kerja (turnover intention), terdapat pengaruh antara ketidaknyamanan kerja terhadap intensi pindah kerja dan terdapat pengaruh secara simultana antara kepuasan kerja dan ketidaknyamanan kerja terhadap intensi pindah kerja. (Muhammad Hanafiah, 2014). Selain itu terdapat penelitian lain mengenai analisis pengaruh stres kerja dan kepuasan kerja terhadap turnover intention karyawan, menunjukan hasil bahwa terdapat pengaruh positif antara stres kerja terhadap turnover intention, dan terdapat pengaruh negatif antara kepuasan kerja terhadap turnover intention karyawan. (Mona Tiorina Manurung, 2012).

Sehingga berdasarkan dari penelitian terdahulu yang telah dilakukan menunjukkan bahwa terdapat berbagai variabel yang memberikan pengaruh terhadap turnover intention pada karyawan ataupun pegawai. Adapun hasil dari penelitian menujukkan bahwa terdapat pengaruh positif terhadap turnover intention dan juga terdapat pengaruh negatif terhadap turnover intention. Hal tersebut menjadi salah satu dasar untuk melanjutkan penelitian terhadap variabel lain untuk mengetahui pengaruhnya terhadap turnover intention ataupun terhadap kinerja karyawan. Sehingga dapat dicegah tejadinya tingkat turnover karyawan atau pegawai yang tinggi dan menjaga tetap optimalnya kinerja pada sumber daya manusia di perusahaan atau organisasi.

\section{Metodologi Penelitian}

Penelitian ini dilakukan pada sebuah perusahaan di Suralaya yang bergerak di bidang unit pembangkit tenaga listrik . Desain penelitian ini bertujuan untuk menjelaskan pengaruh stress kerja dan karakteristik personal terhadap turnover intention, oleh karena itu jenis penelitian yang digunakan adalah metode penelitian penjelasan (explanatory research). Metode penelitian penjelasan (explenatory reasearch) adalah penelitian yang bertujuan untuk menganalisis hubungan-hubungan antara satu variabel dengan variabel lainnya atau bagaimana suatu variabel mempengaruhi variabel lainnya.

Dalam pendekatan ini pendekatan yang digunakan adalah pendekatan kuantitatif karena dilatar belakangi oleh tujuan awal penelitian yaitu menjelaskan mengenai variabelvariabel yang hendak diteliti dan kemudian menguji hipotesis yang telah dirumuskan. Sampel yang diambil $30 \%$ dari populasi, pengambilan data atas dasar sampel apabila 
datanya homogen maka berdasarkan kuantitas sampel diambil 15\% dari populasi dianggap sudah cukup, sehingga pengambilan sampel 30\% dari populasi dapat dianggap sudah memenuhi persyaratan. (Mudrajad Kuncoro, 2009: 128).

Adapun indikator stres kerja meliputi komunikasi yang tidak efektif, perasaan terkucil dan terasingi, kebosanan dan ketidak puasan kerja, kelelahan secara fisik, gangguan pernapasan, gangguan tidur, menunda pekerjaan, menghindari pekerjaan, absen dari pekerjaan. Berikut ini dijelaskan indikator karakteristik personal adalah kemampuan intelektual dan kemampuan fisik. Sedangkan indikator turnover intention adalah usia yang masih produktif, masa jabatan, loyalitas (sense of belonging), jenjang pendidikan yang dimiliki hasil kerja dan peraturan perusahaan. Selanjutnya uji analisis yang dilakukan pada penelitian ini adalah uji validitas, uji reliabilitas, uji normalitas, uji homogenitas, analisis koefisien determinasi, uji t, dan uji F. Data-data pada penelitian diolah dan diuji dengan menggunakan program statistical product and service solution, untuk menganalis korelasi, regresi linier, deskriptif, uji validitas, dan lain-lain. (Duwi Priyatno, 2013).

\section{Hasil dan Pembahasan}

Berikut ini ditampilkan hasil profil responden menurut jenis kelamin, umur, dan tingkat pendidikan. 
Tabel 1. Profil Responden Berdasarkan Jenis Kelamin

\begin{tabular}{|l|c|c|}
\hline \multirow{2}{*}{$\begin{array}{l}\text { Jenis } \\
\text { kelamin }\end{array}$} & \multicolumn{2}{|c|}{ Jumlah } \\
\cline { 2 - 3 } & Frekuensi & $\%$ \\
\hline Pria & 84 & $100 \%$ \\
\hline Wanita & 0 & 0 \\
\hline Total & 84 & $100 \%$ \\
\hline
\end{tabular}

Tabel 3. Profil Responden Berdasarkan Tingkat Pendidikan

\begin{tabular}{|l|c|c|}
\hline \multirow{2}{*}{ Pendidikan } & \multicolumn{2}{|c|}{ Jumlah } \\
\cline { 2 - 3 } & Frekuensi & Presentase\% \\
\hline $\begin{array}{l}\text { SMA/ } \\
\text { Sederajat }\end{array}$ & 48 & $57 \%$ \\
\hline D1-D3 & 26 & $31 \%$ \\
\hline S1 & 10 & $12 \%$ \\
\hline Total & 84 & $100 \%$ \\
\hline
\end{tabular}

Tabel 2. Profil Responden Berdasarkan Kelompok Umur

\begin{tabular}{|c|c|c|}
\hline \multirow{2}{*}{ Usia } & \multicolumn{2}{|c|}{ Jumlah } \\
\cline { 2 - 3 } & Frekuensi & Presentase\% \\
\hline $\begin{array}{l}20-35 \\
\text { Tahun }\end{array}$ & 60 & $71 \%$ \\
\hline $\begin{array}{l}36-45 \\
\text { Tahun }\end{array}$ & 20 & $24 \%$ \\
\hline $\begin{array}{l}45-55 \\
\text { Tahun }\end{array}$ & 4 & $5 \%$ \\
\hline Total & 84 & $100 \%$ \\
\hline
\end{tabular}

Tabel 4. Profil Responden Berdasarkan Lama Kerja

\begin{tabular}{|c|c|c|}
\hline \multirow{2}{*}{ Lama Kerja } & \multicolumn{2}{|c|}{ Jumlah } \\
\cline { 2 - 3 } & Frekuensi & Presentase \% \\
\hline$<2$ Tahun & 20 & $24 \%$ \\
\hline $2-5$ Tahun & 40 & $48 \%$ \\
\hline$>5$ Tahun & 24 & $29 \%$ \\
\hline Total & 84 & $100 \%$ \\
\hline
\end{tabular}

Berdasarkan hasil yang ditunjukan pada tabel di atas terlihat bahwa semua responden pada penelitian ini adalah laki-laki, usia dominan antara 20 hingga 35 tahun, dengan pendidikan mayoritas SMA/sederajat, dan lama kerja antara 2-5 tahun.

Selanjutnya berikut ini disajikan hasil rekapitulasi tanggapan responden terhadap instrumen-instrumen pada variabel stres kerja, karakteristik personal, dan turnover intension. 
Tabel 5. Rekapitulasi Tanggapan Responden Mengenai Stres Kerja (X1).

\begin{tabular}{|c|c|c|c|c|c|c|c|c|c|c|c|c|c|}
\hline $\begin{array}{l}\text { No. } \\
\text { Kuis }\end{array}$ & \multicolumn{2}{|c|}{ STS } & \multicolumn{2}{|c|}{ TS } & \multicolumn{2}{|c|}{$\mathrm{CS}$} & \multicolumn{2}{|c|}{ S } & \multicolumn{2}{|c|}{ SS } & \multicolumn{2}{|c|}{$\begin{array}{c}\text { Jumlah } \\
\text { keseluruhan }\end{array}$} & \multirow[t]{2}{*}{ Keterangan } \\
\hline \multirow[b]{2}{*}{ SK1 } & F & $\mathrm{P}(\%)$ & F & $\mathrm{P}(\%)$ & F & $\mathrm{P}(\%)$ & F & $\mathrm{P}(\%)$ & F & $\mathrm{P}(\%)$ & $\mathrm{F}$ & $\mathrm{P}(\%)$ & \\
\hline & 12 & $14 \%$ & 46 & $55 \%$ & 11 & $13 \%$ & 15 & $18 \%$ & 0 & $0 \%$ & 167 & $100 \%$ & Tidak baik \\
\hline SK2 & 29 & $35 \%$ & 46 & $55 \%$ & 5 & $6 \%$ & 4 & $5 \%$ & 0 & $0 \%$ & 152 & $100 \%$ & Tidak baik \\
\hline SK3 & 13 & $15 \%$ & 45 & $54 \%$ & 13 & $15 \%$ & 12 & $14 \%$ & 1 & $1 \%$ & 195 & $100 \%$ & Cukup \\
\hline SK4 & 6 & $7 \%$ & 53 & $63 \%$ & 17 & $20 \%$ & 8 & $10 \%$ & 0 & $0 \%$ & 195 & $100 \%$ & Tidak baik \\
\hline SK5 & 10 & $12 \%$ & 51 & $61 \%$ & 14 & $17 \%$ & 9 & $11 \%$ & 0 & $0 \%$ & 190 & $100 \%$ & Tidakbaik \\
\hline SK6 & 22 & $26 \%$ & 41 & $49 \%$ & 14 & $17 \%$ & 7 & $8 \%$ & 0 & $0 \%$ & 174 & $100 \%$ & Tidak baik \\
\hline SK7 & 4 & $5 \%$ & 31 & $37 \%$ & 21 & $25 \%$ & 17 & $20 \%$ & 11 & $13 \%$ & 252 & $100 \%$ & Cukup \\
\hline SK8 & 16 & $19 \%$ & 41 & $49 \%$ & 18 & $21 \%$ & 4 & $5 \%$ & 5 & $6 \%$ & 193 & $100 \%$ & Tidak baik \\
\hline SK9 & 10 & $12 \%$ & 39 & $46 \%$ & 18 & $21 \%$ & 11 & $13 \%$ & 6 & $7 \%$ & 216 & $100 \%$ & Tidak baik \\
\hline SK10 & 4 & $5 \%$ & 37 & $44 \%$ & 22 & $26 \%$ & 16 & $19 \%$ & 5 & $6 \%$ & 238 & $100 \%$ & Cukup \\
\hline \multicolumn{11}{|c|}{ Jumlah Keseluruhan } & 1972 & & \multirow{2}{*}{ Tidak Baik } \\
\hline \multicolumn{11}{|c|}{ Rata - Rata } & \multicolumn{2}{|l|}{197,2} & \\
\hline
\end{tabular}

Berdasarkan hasil yang ditampilkan pada tabel di atas menunjukkan bahwa tanggapan terhada variabel stres kerja sebagian besar tidak baik terdapat tujuh intrumen, sedangkan nilai cukup terdapat pada tiga instrumen. Artinya masih banyak karyawan yang mengalami stres kerja.

Tabel 6. Rekapitulasi Tanggapan Responden Mengenai Karakteristik Personal (X2).

\begin{tabular}{|c|c|c|c|c|c|c|c|c|c|c|c|c|c|}
\hline $\begin{array}{l}\text { No. } \\
\text { Kuis }\end{array}$ & & STS & & TS & & $\mathrm{CS}$ & & $\mathbf{S}$ & & SS & $\begin{array}{r}\mathbf{J} \\
\text { kese }\end{array}$ & $\begin{array}{l}\text { ah } \\
\text { han }\end{array}$ & Keterangan \\
\hline$V \mathrm{D} 1$ & $\mathbf{F}$ & $\mathbf{P}(\%)$ & $\mathbf{F}$ & $\mathbf{P}(\%)$ & $\mathbf{F}$ & $\mathbf{P}(\%)$ & $\mathbf{F}$ & $\mathbf{P}(\%)$ & $\mathbf{F}$ & $\mathbf{P}(\%)$ & $\mathbf{F}$ & $\mathbf{P}(\%)$ & \\
\hline$N 1$ & 0 & $0 \%$ & 0 & $0 \%$ & 20 & $24 \%$ & 54 & $64 \%$ & 10 & $12 \%$ & 326 & $100 \%$ & Baik \\
\hline KP2 & 0 & $0 \%$ & 2 & $2 \%$ & 22 & $26 \%$ & 47 & $56 \%$ & 13 & $15 \%$ & 323 & $100 \%$ & Baik \\
\hline KP3 & 0 & $0 \%$ & 20 & $24 \%$ & 10 & $12 \%$ & 34 & $40 \%$ & 20 & $24 \%$ & 396 & $100 \%$ & Sangat baik \\
\hline KP4 & 3 & $4 \%$ & 6 & $7 \%$ & 16 & $19 \%$ & 53 & $63 \%$ & 6 & $7 \%$ & 335 & $100 \%$ & Baik \\
\hline KP5 & 0 & $0 \%$ & 5 & $6 \%$ & 26 & $31 \%$ & 47 & $56 \%$ & 6 & $7 \%$ & 311 & $100 \%$ & Baik \\
\hline KP6 & 0 & $0 \%$ & 1 & $1 \%$ & 24 & $29 \%$ & 37 & $44 \%$ & 22 & $26 \%$ & 328 & $100 \%$ & Baik \\
\hline KP7 & 0 & $0 \%$ & 4 & $5 \%$ & 14 & $17 \%$ & 57 & $68 \%$ & 9 & $11 \%$ & 323 & $100 \%$ & Baik \\
\hline KP8 & 0 & $0 \%$ & 2 & $2 \%$ & 16 & $19 \%$ & 54 & $64 \%$ & 12 & $14 \%$ & 328 & $100 \%$ & Baik \\
\hline KP9 & 1 & $1 \%$ & 5 & $6 \%$ & 16 & $19 \%$ & 54 & $64 \%$ & 8 & $10 \%$ & 315 & $100 \%$ & Baik \\
\hline KP10 & 0 & $0 \%$ & 2 & $2 \%$ & 19 & $23 \%$ & 56 & $67 \%$ & 7 & $8 \%$ & 320 & $100 \%$ & Baik \\
\hline & & & & Jumlah & Kes & luruhar & & & & & 3305 & & \\
\hline & & & & $\mathbf{R a}$ & $a-1$ & lata & & & & & 330,5 & & Baik \\
\hline
\end{tabular}


Berdasarkan hasil yang ditampilkan pada tabel di atas menunjukkan bahwa tanggapan terhada variebel karakteristik personal sebagian besar baik terdapat delapan intrumen, sedangkan sangat baik terdapat pada dua instrumen. Artinya banyak karyawan yang memiliki karakteristik personal yang baik.

Tabel 7. Rekaitulasi tanggapan responden mengenai Turnover Intention (Y).

\begin{tabular}{|c|c|c|c|c|c|c|c|c|c|c|c|c|c|}
\hline \multirow[t]{2}{*}{$\begin{array}{l}\text { No. } \\
\text { Kuis }\end{array}$} & \multicolumn{2}{|c|}{ STS } & \multicolumn{2}{|r|}{ TS } & \multicolumn{2}{|c|}{ CS } & \multicolumn{2}{|r|}{$\mathbf{S}$} & \multicolumn{2}{|c|}{ SS } & \multicolumn{2}{|c|}{$\begin{array}{c}\text { Jumlah } \\
\text { Keseluruhan }\end{array}$} & \multirow[t]{2}{*}{ Keterangan } \\
\hline & $\mathbf{F}$ & $\mathbf{P}(\%)$ & $\mathbf{F}$ & $\mathbf{P}(\%)$ & $\mathbf{F}$ & $\mathbf{P}(\%)$ & $\mathbf{F}$ & $\mathbf{P}(\%)$ & $\mathbf{F}$ & $\mathbf{P}(\%)$ & $\mathbf{F}$ & $\mathbf{P}(\%)$ & \\
\hline SK1 & 0 & $0 \%$ & 3 & $4 \%$ & 18 & $21 \%$ & 46 & $55 \%$ & 17 & $20 \%$ & 329 & $100 \%$ & Baik \\
\hline SK2 & 0 & $0 \%$ & 7 & $8 \%$ & 26 & $31 \%$ & 38 & $45 \%$ & 13 & $15 \%$ & 309 & $100 \%$ & Baik \\
\hline SK3 & 0 & $0 \%$ & 3 & $4 \%$ & 22 & $26 \%$ & 53 & $63 \%$ & 6 & $7 \%$ & 314 & $100 \%$ & Baik \\
\hline SK4 & 0 & $0 \%$ & 8 & $10 \%$ & 20 & $24 \%$ & 53 & $63 \%$ & 3 & $4 \%$ & 303 & $100 \%$ & Baik \\
\hline SK5 & 0 & $0 \%$ & 1 & $1 \%$ & 14 & $17 \%$ & 57 & $68 \%$ & 12 & $14 \%$ & 332 & $100 \%$ & Baik \\
\hline SK6 & 0 & $0 \%$ & 2 & $2 \%$ & 16 & $19 \%$ & 61 & $73 \%$ & 5 & $6 \%$ & 321 & $100 \%$ & Baik \\
\hline SK7 & 0 & $0 \%$ & 1 & $1 \%$ & 7 & $8 \%$ & 48 & $57 \%$ & 28 & $33 \%$ & 355 & $100 \%$ & Baik \\
\hline SK8 & 0 & $0 \%$ & 1 & $1 \%$ & 7 & $8 \%$ & 51 & $61 \%$ & 25 & $30 \%$ & 302 & $100 \%$ & Baik \\
\hline SK9 & 0 & $0 \%$ & 1 & $1 \%$ & 12 & $14 \%$ & 53 & $63 \%$ & 18 & $21 \%$ & 340 & $100 \%$ & Baik \\
\hline SK10 & 0 & $0 \%$ & 1 & $1 \%$ & 11 & $13 \%$ & 55 & $65 \%$ & 17 & $20 \%$ & 340 & $100 \%$ & Baik \\
\hline \multicolumn{11}{|c|}{ Jumlah keseluruhan } & 3245 & & \multirow{2}{*}{ Baik } \\
\hline \multicolumn{11}{|c|}{ Rata - Rata } & 324,5 & & \\
\hline
\end{tabular}

Berdasarkan hasil yang ditampilkan pada tabel di atas menunjukkan bahwa tanggapan terhada variebel turnover intension semuanya baik. Artinya banyak karyawan yang tidak mengharapkan tingginya turnover intention. Selanjutnya akan disajikkan tabel hasil uji validitas butir-butir instrumen.

Tabel 8. Hasil Uji Validitas X1, X2, dan X3.

\begin{tabular}{|l|l|l|l|l|l|l|l|l|}
\hline Item & $\mathrm{r}$ hitung & $\mathrm{r}$ tabel & Item & $\mathrm{r}$ hitung & $\mathrm{r}$ tabel & Item & $\mathrm{r}$ hitung & $\mathrm{r}$ tabel \\
\hline KP 1 & 0.624 & 0.213 & SK 1 & 0.746 & 0.213 & TI 2 & 0.555 & 0.213 \\
\hline KP 2 & 0.705 & 0.213 & SK 2 & 0.621 & 0.213 & TI 3 & 0.666 & 0.213 \\
\hline KP 3 & 0.592 & 0.213 & SK 3 & 0.758 & 0.213 & TI 4 & 0.600 & 0.213 \\
\hline KP 4 & 0.749 & 0.213 & SK 4 & 0.775 & 0.213 & TI 5 & 0.587 & 0.213 \\
\hline KP 5 & 0.682 & 0.213 & SK 5 & 0.842 & 0.213 & TI 6 & 0.422 & 0.213 \\
\hline KP 6 & 0.785 & 0.213 & SK 6 & 0.792 & 0.213 & TI 7 & 0.565 & 0.213 \\
\hline KP 7 & 0.822 & 0.213 & SK 7 & 0.718 & 0.213 & TI 8 & 0.724 & 0.213 \\
\hline KP 8 & 0.727 & 0.213 & SK 8 & 0.851 & 0.213 & TI 9 & 0.761 & 0.213 \\
\hline KP 9 & 0.788 & 0.213 & SK 9 & 0.771 & 0.213 & TI 10 & 0.666 & 0.213 \\
\hline KP 10 & 0.715 & 0.213 & SK 10 & 0.769 & 0.213 & & & \\
\hline
\end{tabular}

Berdasarkan hasil yang ditunjukkan pada tabel di atas maka dapat dinyatakan bahwa semua butir-butir instrumen valid, karena nilai t hitung lebih besar dari nilai $r$ tabel $=0.213$. 
Tabel 9. Hasil Pengujian Reliabilitas.

\begin{tabular}{|c|c|c|c|}
\hline Variabel & $\begin{array}{c}\text { Nilai } \\
\text { Alpha }\end{array}$ & $\begin{array}{l}\text { Rule Of } \\
\text { Thumb } \\
\text { Normaly }\end{array}$ & Kesimpulan \\
\hline Stres Kerja (X1) & 0.918 & 0.60 & Reliabel \\
\hline $\begin{array}{c}\text { Karakteristik Personal } \\
\text { (X2) }\end{array}$ & 0.893 & 0.60 & Reliabel \\
\hline Turnover Intention(Y) & 0.805 & 0.60 & Reliabel \\
\hline
\end{tabular}

Berdasarkan nilai yang ditunjukkan pada tabel di atas maka dapat dinyatakan semua butir-butir instrumen pada penelitian dianggap reiabel, karena semua nilai Alpha Cronbrach di atas 0.6.

Selanjutnya analisis koefisien determinasi menunjukan berapa persen dari variasi (naik turunnya) variabel dependent dapat dijelaskan oleh variasi variabel independent. Koefisien determinasi merupakan koefisien korelasi dan dinyatakan dalambentuk persen.

Tabel 10. Koefisien Determinasi Parsial variabel X1 Terhadap variabel Y.

Model Summary

\begin{tabular}{|r|r|r|rr|}
\hline Model $R$ & R Square & Adjusted R Square & $\begin{array}{l}\text { Std. Error of the } \\
\text { Estimate }\end{array}$ \\
\hline $.488^{\mathrm{a}}$ & .238 & .229 & \multicolumn{2}{|c|}{3.3539} \\
\hline
\end{tabular}

Berdasarkan tabel diatas hasil perhitungan antara koefisien determinasi parsial variabel stres kerja terhadap turnover intention diperoleh nilai sebesar $\mathrm{R}^{2}=0,238$ dengan perhitungan koefisien determinasi untuk mengetahui besarnya kontribusi hubungan variabel stres kerja (X1) terhadap turnover intention (Y) sebesar $23.8 \%$.

Tabel 11. Koefisien Determinasi Parsial variabel X2 Terhadap variabel Y.

Model Summary

\begin{tabular}{|r|r|r|lr|}
\hline Model $R$ & R Square & Adjusted R Square & $\begin{array}{l}\text { Std. Error of the } \\
\text { Estimate }\end{array}$ \\
\hline $.710^{\mathrm{a}}$ & .504 & .498 & \multicolumn{2}{|c|}{2.69072} \\
\hline
\end{tabular}

Berdasarkan tabel diatas hasil perhitungan antara koefisien determinasi parsial variabel stres kerja terhadap turnover intention diperoleh nilai sebesar $\mathrm{R}^{2}=0,504$ dengan 
perhitungan koefisien determinasi untuk mengetahui besarnya kontribusi hubungan variabel karakteristik personal (X2) terhadap turnover intention (Y) sebesar 50.4\%.

Tabel 12. Koefisien Determinasi Parsial variabel X2 Terhadap variabel Y.

Model Summary

\begin{tabular}{|c|c|c|c|}
\hline Model $R$ & $R$ Square & Adjusted $R$ Square & $\begin{array}{c}\text { Std. Error of the } \\
\text { Estimate }\end{array}$ \\
\hline $.726^{\mathrm{a}}$ & .527 & .516 & 2.64265 \\
\hline
\end{tabular}

Berdasarkan tabel di atas bahwa diketahui koefisien determinasi (R Square) yang diperoleh sebesar 0.527 dengan perhitungan koefisien determinasi untuk mengetahui besarnya kontribusi hubungan variabel stres kerja dan karakteristik personal terhadap turnover intention sebesar 52.7\%. Hal ini dapat diartikan bahwa variabel stres kerja dan karakteristik personal mempengaruhi sebesar $52.7 \%$ terhadap turnover intention sedangkan sisanya sebesar $47.3 \%$ dipengaruhi oleh faktor lain.

Adapun hasil uji hipotesis ketiga yaitu X1 dan X2 terhadap Y, mendapatkan hasil sebagai berikut. Ho: $\beta 3=0$, artinya tidak ada pengaruh yang signifikan dari stres kerja dan karakteristik personal terhadap turnover intention. Ha: $\beta 3 \neq 0$, artinya ada pengaruh yang signifikan dari stres kerja dan Karakteristik personal terhadap turnover intention. Berikutnya dilakukan uji $\mathrm{F}$ dengan tujuan untuk menguji signifikansi apakah hipotesis yang diterapkan semula diterima atau ditolak, dengan cara membandingkan antara F hitung dengan $\mathrm{F}$ tabel.

Selanjutnya diperoleh hasil dengan dasar pengambilan kesimpulan uji F diperoleh hasil sebagai berikut.

a) Jika nilai signifikan $<$ dari 0.05 atau $\mathrm{F}$ hitung $>$ dari $\mathrm{F}$ tabel maka terdapat pengaruh variabel X1 dan X2 terhadap Y.

b) Jika nilai sinifikan $>$ dari 0.05 atau $\mathrm{F}$ hitung lebih $<$ dari $\mathrm{F}$ tabel maka tidak terdapat pengaruh variabel $\mathrm{X}$ terhadap $\mathrm{Y}$.

Berdasarkan uji tersebut maka diketahui apakah karakteristik personal berpengaruh terhadap turnover intention, untuk mencari tahu $F$ tabel sebagai perbandingan $t$ hitung yaitu $: \mathrm{F}$ tabel $=\mathrm{F}(\mathrm{k} ; \mathrm{n}-\mathrm{k}) \mathrm{F}$ tabel $=\mathrm{F} 2 ; 84-2, \mathrm{~F}$ tabel $=2 ; 82=3.11$ maka $\mathrm{t}$ tabelnya sebesar 3.11. selain dari pada itu diperoleh hasil dari perhitungan bahwa nilai signifikan karakteristik personal $0.000<$ dari 0.05 atau taraf nyata dan nilai $\mathrm{F}$ hitung $45.200>$ dari $\mathrm{t}$ 
tabel 3.11 yang berarti Ho ditolak dan Ha3 diterima, itu artinya ada pengaruh yang signifikan antara Stres Kerja dan Karakteristik Personal terhadap Turnover Intention.

Selanjutnya untuk uji t diperoleh nilai untuk menentukan penerimaan hipotesis secara parsial. Diperoleh nilai signifikansi t hitung sebesar 0.49 lebih kecil dari $0.05(\alpha)$ dan t hitung sebesar -2.002 lebih kecil dari t tabel yaitu sebesar 1.993 dengan menggunakan tingkat signifikansi 5\%. Dengan demikian hipotesis pertama diterima sehingga menyatakan adanya pengaruh yang negatif antara X1 terhadap Y. Selanjutnya diperoleh nilai signifikansi t hitung sebesar 0.000 lebih kecil dari $0.05(\alpha)$ dan thitung sebesar 7.045 lebih besar dari t tabel yaitu sebesar 1.993 dengan menggunakan tingkat signifikansi 5\% dengan demikian hipotesis kedua diterima sehingga menyatakan adanya pengaruh yang positif yang signifikan antara X2 terhadap Y.

Berdasarkan analisis regresi linear beganda yaitu uji $\mathrm{F}$ diperoleh nilai untuk menentukan penerimaan hipotesis secara bersama. Diperoleh nilai signifikansi $\mathrm{F}$ hitung sebesar 0.000 lebih kecil dari $0.05(\alpha)$ dan diperoleh F hitung sebesar 45.200 lebih besar dari $\mathrm{F}$ tabel yaitu 3.11 dengan tingkat signifikansi 5\%, berdasarkan hasil perhitungan tersebut maka dapat disimpulkan Ho3 ditolak dan Ha3 diterima sehingga dapat dinyatakan adanya pengaruh yang signifikan secara bersama anatara X1 dan X2 terhadap Y.

\section{Pembahasan Hasil Hipotesis}

Selanjutnya untuk mengetahui prediksi antara variabel independent yaitu stres kerja dan karakteristik personal terhadap variabel dependent yaitu variabel turnover intention dengan menggunakan bantuan program statistik, dihasilkan output regresi berganda sebagai berikut. Hasil estimasi model dapat ditulis dalam persamaan dibawah ini : $\ddot{Y}=22.681+(-0.093)$ stres kerja +0.478 karakteristik personal. Persamaan tersebut dapat diartikan sebagai berikut.

1) Konstanta sebesar 22.851 menunjukan pengaruh positif variabel independent, variabel independent dianggap konstan $(\mathrm{X} 1=0$ dan $\mathrm{X} 2=0)$, maka tingkat atau besarnya turnover intention (Y) sebesar 0,391.

2) Koefisien regresi stres kerja menandakan negatif sebesar -0,093 berdasarkan data tersebut diuji secara parsial jika stres kerja meningkat maka secara otomatis turnover intention mengalami penurunan.

3) Koefisien resgresi karakteristik personal menandakan positif sebesar 0,478 berdasarkan data tersebut diuji secara parsial jika karakteristik personal menurun maka turnover intention meningkat. 


\section{KESIMPULAN DAN SARAN}

Berdasarkan hasil penelitian dan pembahasan yang telah dilakukan peneliti mengenai Pengaruh Stres Kerja dan Karakteristik Personal terhadap Turnover Intention pegawai maka kesimpulan sebagai berikut : 1) Berdasarkan nilai t hitung stres kerja > dari $\mathrm{t}$ tabel dan nilai signifikansi < dari 0.05 dengan tingkat pengaruh sebesar $23.8 \%$, stres kerja berpengaruh negative terhadap turnover intention pegawai. 2) Berdasarkan nilai t hitung karakteristik personal $>\mathrm{t}$ tabel dan nilai signifikansi $<$ dari 0.05 dengan tingkat pengaruh 50,4\%, artinya terdapat pengaruh positif dan signifikan Karakteristik Personal terhadap Turnover Intention pegawai. 3)Berdasarkan nilai $\mathrm{F}$ hitung stres kerja dan karakteristik personal > dari $\mathrm{F}$ tabel dan nilai signifikansi < dari 0.05 artinya, Stres Kerja dan Karakteristik Personal berpengaruh secara simultan terhadap turnover intention pegawai. Dilihat dari hasil Koefisien determinasinya variabel stres kerja dan karakteristik personal berpengaruh terhadap turnover intention sebesar $52.7 \%$ dan sisanya $47.3 \%$ dipengaruhi oleh faktor lain. 


\section{DAFTAR PUSTAKA}

Arin Dewi Putrianti, Djamhur Hamid, M. Djudi Mukzam (2014), Pengaruh Kompensasi dan Motivasi Kerja Terhadap Turnover Intention (Studi Pada Karyawan PT. TIKI Jalur Nugraha Ekakurir Pusat Malang). Jurnal Administrasi Bisnis (JAB)|Vol. 12 No. 2 Juli 2014| administrasibisnis.studentjournal.ub.ac.id

Duwi Priyatno (2008), Mandiri Belajar SPSS. Yogyakarta: MediaKom.

Gabriela Syahronica, Moehammad Soe'oed Hakam, Ika Ruhana (2015), Pengaruh Kepuasan Kerja Dan Stres Kerja Terhadap Turnover Intention (Studi Pada Karyawan Departemen Dunia Fantasi PT Pembangunan Jaya Ancol, Tbk). Jurnal Administrasi Bisnis (JAB) Vol. 20 No.1 Maret 2015. administrasibisnis.studentjournal.ub.ac.id

Mona Tiorina Manurung (2012), Analisis Pengaruh Stres Kerja dan kepuasan Kerja Terhadap Turnover Intention Karyawan. Skripsi. Fakultas Ekonomika dan Bisnis Universitas Dipo Negoro Semarang.

Mudrajad Kuncoro (2009), Metode Kuntitatif Teori dan Aplikasi untuk Bisnis dan Aplikasi. Edisi 3. Yogyakarta: UPP STIM YKPN.

Muhammad Hanafiah (2014), Pengaruh Kepuasan Kerja dan Ketidaknyamanan Kerja dengan Intensi Pindah Kerja pada Karyawan PT Buma Desa Suaran Kecamatan Sambaliung Kabupaten Berau. eJournal Psikologi, 1(3): 303-312.

Putu Pande Yudiastra, Gede Sri Darma (2015), Pengaruh Penggunaan teknologi Informasi, Disiplin Kerja, Insentif, Turnover Terhadap Kinerja Pegawai. Jurnal Manajemen dan Bisnis. Volume 12.No.1: 151-176.

Robbins, Stephens P (2003), Perilaku Organisasi, Edisi Kesepuluh, Prentice-Hall, Jakarta.

Rusli. (2016). Pengaruh Karakteristik Individu Dan Lingkungan Kerja terterhadap Semangat Kerja Karyawan Pada Divisi Stockpreparation Pt. Indah Kiat Pulp And Paper. Serang: Universitas Serang Raya. 